J. Clin. Chem. Clin. Biochem.

Vol. 23, 1985, pp. 17-20

\title{
Sterile Isolation of Polymorphonuclear Leukocytes from Large Blood Volumes
}

\author{
By H. Kelbak \\ Medical Gastroenterological Department C, Herlev University Hospital, Herlev, Denmark
}

(Received April 27/August 6, 1984)

Summary: A method for preparation of pure polymorphonuclear leukocyte populations from large blood volumes is described. Methyl cellulose sedimentation and hypotonic haemolysis resulted in an efficient removal of erythrocytes. Subsequent separation with sodium metrizoate/Ficoll (density 1.077) gave rise to a preparation containing $95 \%$ polymorphonuclear leukocytes with a recovery of $56 \%$ and complete exclusion of red cell ghosts. The granulocyte function expressed by chemotaxis to the standard attractant casein and by trypan blue exclusion was not influenced by the separation procedure, which may be applied prior to granulocyte labeling for studies of cell kinetics and inflammatory disease.

\section{Verfahren zur sterilen Isolierung polymorphkerniger Leukocyten aus großen Blutvolumina}

Zusammenfassung: Ein Verfahren zur Gewinnung reiner polymorphkerniger Leukocyten-Populationen aus großen Blutvolumina wird beschrieben. Sedimentation unter Verwendung von Methylcellulose und hypotone Hämolyse führten zu einer wirksamen Entfernung der Erythrocyten. Nachfolgende Separierung mit NatriumMetrizoat/Ficoll (Dichte 1,077 kg/l) ergab eine Präparation, die $95 \%$ polymorphkernige Leukocyten mit einer Ausbeute von $56 \%$ enthielt. Plasmamembranen von Erythrocyten fanden sich im Präparat nicht. Die Funktion der Granulocyten, geprüft durch Chemotaxis gegenüber dem als Standard-Reiz verwendeten Casein und durch Trypanblau-Ausschluß, wurde durch das Trennverfahren nicht beeinflußt. Das Trennverfahren kann vor der Markierung der Granulocyten für Untersuchungen von Zellkinetiken und entzündlichen Erkrankungen verwendet werden.

\section{Introduction}

The preparation of pure populations of polymorphonuclear leukocytes is an important first step for the investigation of immunological diseases in man. In addition, the study of the kinetics of polymorphonuclear leukocytes requires purification of cells prior to labeling $(1,2)$. The method of Böyum (3) has been modified by optimizing the density of Hypaque-Ficoll (4) and by using discontinuous gradients of the separation medium $(5-8)$. In the present study a method for purification of granulocytes from large blood volumes is presented in order to obtain a large sterile amount of polymorphonuclear leukocytes for labeling.

\section{Material and Methods}

Blood sampling

About $120 \mathrm{ml}$ of blood was drawn from an antecubital vein of 9 healthy volunteers (laboratory staff) into blood bags $(600 \mathrm{ml}$ capacity, Travenol Laboratories S.A., Castlebar, Ireland) using ethylene diamine tetraacetate (EDTA, Merck, Darmstadt, FRG) as anti-coagulant (10 mmol/l blood).

The following procedures except for centrifugation were carried out in a laminar flow bench (Holten, Allerød, DK) in order to provide sterility.

\section{Red blood cell sedimentation}

Anti-coagulated blood was drawn from the bag into $60 \mathrm{ml}$ disposable syringes (Braun Melsungen, FRG) containing methyl cellulose ( $20 \mathrm{~g} / \mathrm{l})$ (Apodan, Copenhagen, Denmark). Red blood cells were allowed to settle for $\mathbf{4 5}$ minutes in the 


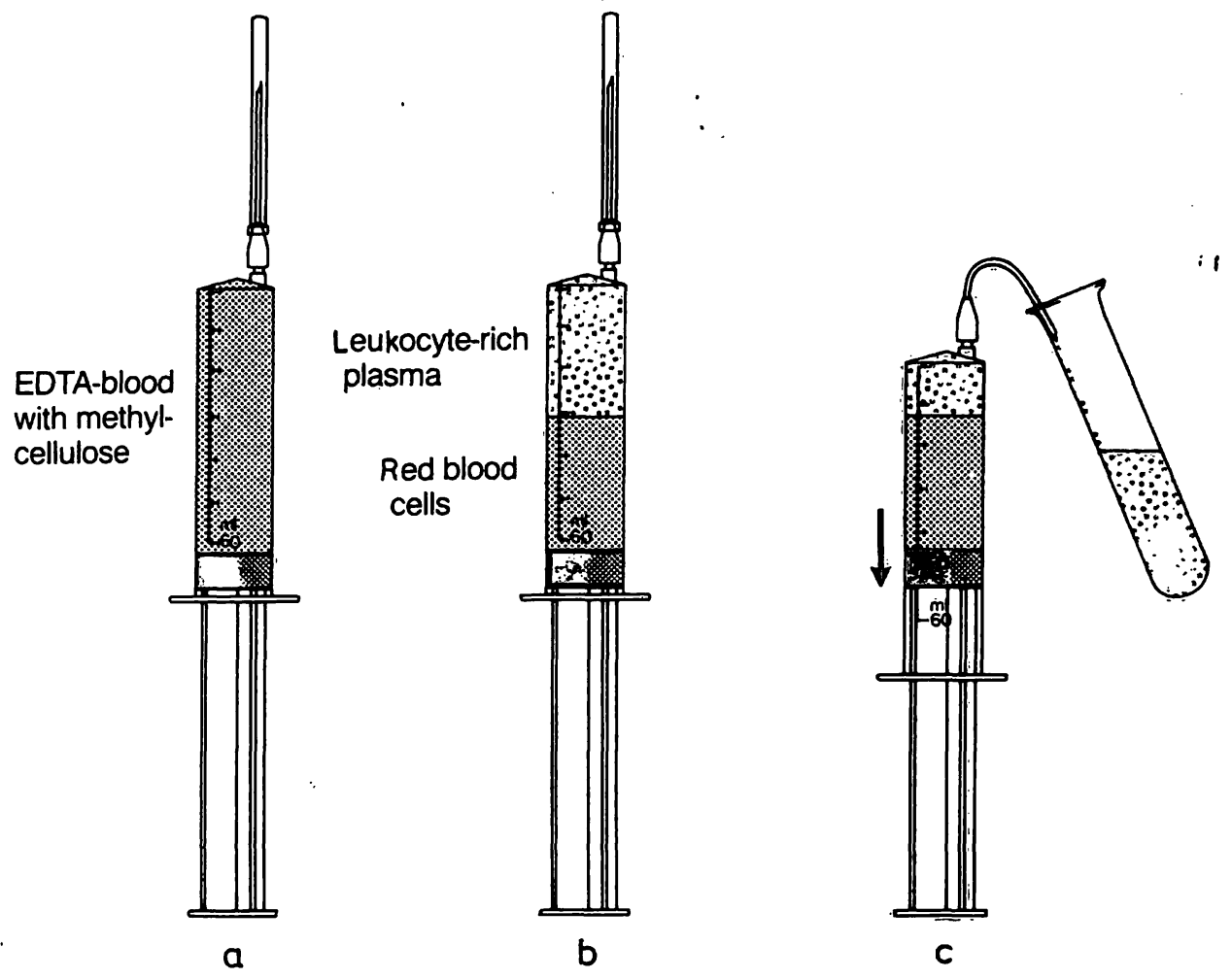

Fig. 1. Red blood cell sedimentation in methyl cellulose (2\%) in a $60 \mathrm{ml}$ syringe (a-b) and expulsion of the buffy coat (c).

Tab. 1. Parameters of polymorphonuclear leukocyte separation (mean \pm SD).

\begin{tabular}{lllll}
\hline $\begin{array}{l}\text { Number of } \\
\text { subjects }\end{array}$ & $\begin{array}{l}\text { Volume of } \\
\text { whole blood } \\
(\mathrm{ml})\end{array}$ & $\begin{array}{l}\text { Purity of polymorpho- } \\
\text { nuclear leukocytes in final } \\
\text { suspension (\%) }\end{array}$ & $\begin{array}{l}\text { Recovery of } \\
\text { polymorphonuclear } \\
\text { leukocytes (\%) }\end{array}$ & $\begin{array}{l}\text { Red blood cell } \\
\text { contamination }\end{array}$ \\
\hline 9 & $116 \pm 27$ & $94.8 \pm 3.2$ & $55.7 \pm 13.3$ & $\leq 1 \%$ \\
\hline
\end{tabular}

syringes (fig. 1). The leukocyte- and plateletrich buffy coat was easily expelled through a bended phlebotomy needle $(1.2 \times$ $40 \mathrm{~mm})$ into siliconized polycarbonate tubes $(16 \times 110 \mathrm{~mm}$ (Nunc, Roskilde, DK)). After centrifugation at $200 \mathrm{~g}(5 \mathrm{~min})$ the pellets were pooled into one tube and washed twice in Gey's solution') including glucose $(2 \mathrm{~g} / \mathrm{l})$ and human albumin $(20 \mathrm{~g} / \mathrm{l})$.

\section{Haemolysis}

The cell pellet was exposed to $2.0 \mathrm{ml}$ of hypotonic $\mathrm{NaCl}(2 \mathrm{~g} / \mathrm{l})$ at $4^{\circ} \mathrm{C}$, the suspension mixed vigorously for $20 \mathrm{~s}$ and isotonicity restored by rapid addition of $2.0 \mathrm{ml}$ of hypertonic $\mathrm{NaCl}$ $(16 \mathrm{~g} / \mathrm{l})$. The preparation was washed in Gey's solution and lysis was repeated. After another washing the supernatant was discarded and Gey's medium was added to make a volume of $6 \mathrm{ml}$ of leukocyte suspension.

\section{White cell separation}

The $6 \mathrm{ml}$ of cell suspension was carefully layered upon $4 \mathrm{ml}$ of a mixture of sodium metrizoate $(96 \mathrm{~g} / \mathrm{l})$ and Ficoll $(56 \mathrm{~g} / \mathrm{l})$ with

1) Gey's solution: $\mathrm{NaCl}(8 \mathrm{~g} / 1), \mathrm{KCl}(0.375 \mathrm{~g} / \mathrm{l}), \mathrm{NaH}_{2} \mathrm{PO}_{4}$ $(0.15 \mathrm{~g} / \mathrm{l}), \mathrm{KH}_{2} \mathrm{PO}_{4}(0.025 \mathrm{~g} / \mathrm{l}), \mathrm{NaHCO}_{3}(0.25 \mathrm{~g} / \mathrm{l}), \mathrm{CaCl}_{2}$ $(0.275 \mathrm{~g} / \mathrm{l}), \mathrm{MgCl}_{2}(0.21 \mathrm{~g} / \mathrm{l})$. a mass density of $1.077 \mathrm{~kg} / \mathrm{l}$ (Lymphoprep, Nyegaard, Oslo, Norway) in a siliconized polycarbonate tube $(16 \mathrm{~mm}$ diameter). The tube was centrifuged for $30 \mathrm{~min}$ at $20^{\circ} \mathrm{C}$ and $400 \mathrm{~g}$. The supernatant fractions consisting of

1) Gey's medium,

2) an interphase layer of mononuclear white cells and platelets and

3) Lymphoprep

were discarded and the polymorphonuclear leukocyte pellet was washed twice and suspended in Gey's medium.

\section{Cell counting}

Cell countings of whole blood and cell preparations were determined using a Neubauer chamber after staining with methyl violet acetic acid. Smears were prepared and differential counts were performed after staining with May-Grünwald/ Giemsa (eosin-methylene blue/azur-eosin-methylene blue).

\section{Polymorphonuclear leukocyte function}

The chemotactic function of polymorphonuclear leukocytes was investigated in modified Boyden chambers with $3 \mu \mathrm{m}$ pore size Sartorius ${ }^{R}$ filters after incubation for $45 \mathrm{~min}$ at $37^{\circ} \mathrm{C}$. Polymorphonuclear leukocytes $\left(2 \times 10^{\circ}\right)$ were added to the upper compartment, and casein $(5 \mathrm{~g} / \mathrm{l})$ dissolved at $\mathrm{pH} 12$ in 
Gey's solution served as an attractant. Spontaneous motility was assessed with Gey's solution in both chamber compartments. Migration was measured by the leading front technique (9) and presented as the mean of 5 determinations on each of two filters.

The viability of polymorphonuclear leukocytes was further tested by counting 200 cells in the trypan blue exclusion test.

\section{Sterility test}

Cell suspensions were placed on cultivating plates and incubated for 7 days before reading.

\section{Results}

The yield of polymorphonuclear leukocytes in the final suspensions are shown in table 1. Eosinophils comprised the most common non-neutrophil cell type while only a few per cent of mononuclear leukocytes, and almost no erythrocytes were found in the polymorphonuclear leukocyte suspension.

Red cell ghosts, a product of haemolysis, were avoided in the final polymorphonuclear leukocyte suspension, but were often visible in the interphase layer after sodium metrizoate/Ficoll separation.

The chemotactic function of purified polymorphonuclear leukocytes was $108 \pm 13 \mu \mathrm{m} / 45 \mathrm{~min}$ after casein stimulation (mean $\pm \mathrm{SD}$ ), while the spontaneous chemotaxis against Gey's medium was $45 \pm 7$ $\mu \mathrm{m} / 45 \mathrm{~min}$. These migration values are within normal limits of our laboratory.

The viability test showed an uptake of trypan blue by $1-2 \%$ of the polymorphonuclear leukocytes in the final suspension.

Culturing of cell preparations did not reveal bacterial growth.

\section{Discussion}

Difficulties have been experienced in producing pure populations of polymorphonuclear leukocytes. Böyum (4) has described the isolation of mononuclear cells from whole blood by aid of a separation fluid with a suitable density. Dextran and methyl cellulose have been introduced as erythrocyte clumping agents $(10,11)$ and a combination of the procedures has been widely used $(12,13)$. In order to obtain pure polymorphonuclearleukocyte solutions, lysis of remaining erythrocytes is necessary. This procedure results in red cell ghosts which are difficult to remove from the cell suspension without repeated washing.

The present study reports a procedure which allows an efficient separation of polymorphonuclear leukocytes from large amounts of blood, under sterile conditions, with a recovery of polymorphonuclear leukocytes corresponding to the values obtained by Böyum (3) and Hjort et al. (6). The erythrocyte contamination of the final suspension is negligible, and red cell ghosts formed as a result of hypotonic haemolysis are sedimented in the sodium metrizoate/ Ficoll interphase layer which is discarded. Cell suspensions obtained from large blood volumes, i. e. suspensions of leukocytes in high concentration, were separated efficiently by gradient centrifugation through sodium metrizoate/Ficoll.

In some preparations the polymorphonuclear leukocytes tended to form microscopic or macroscopic clumps, probably due to the high concentration of cells. Cell function, however, was not influenced by this phenomenon, which may be reduced by adding streptokinase to the preparation (14) or by adjustments of the ion composition of the Gey's medium.

It can be claimed that the method described in this paper has the weakness of being time consuming compared to some of the more rapid techniques described previously $(4-6,8,15)$. However, it seems to be the most efficient procedure for obtaining pure polymorphonuclear leukocyte preparations with a minimum of red cell contamination from a large amount of blood. The method might be convenient for labeling polymorphonuclear leukocytes with radioactive isotopes for studies of cell kinetics or in scintigraphic investigations of inflammatory disease.

\section{Acknowledgements}

Thanks are due to Kirsten Bülow for laboratory technical assistance.

This work was supported by the Foundation of Carl J. Becker.

\section{References}

1. Weiblen, B. J., Forstrom, L. \& McCullough, J. (1978) J. Lab. Clin. Med. 94, 246-255.

2. Zakhireh, B., Thakur, M. L., Malech, H. L., Cohen, M.S., Gottschalk, A. \& Root, R. K. (1979) J. Nucl. Med. 20, $741-747$

3. Böyum, A. (1968) Scand. J. Clin. Lab. Invest. 21 (Suppl. 97), 77-89.

4. Ferrante, A. \& Thong, Y. A. (1978) J. Immunol. Methods $24,389-393$.

5. Aguado, M. T., Pujol, N., Rubiol, E., Tura, M. \& Celada, A. (1980) J. Immunol. Methods 32, 41-50.

6. Hjorth, R., Jonsson, A.-K. \& Vretblad, P. (1981) J. Immunol Methods 43, 95-101.

7. Bicalho, H.M.S., Gontijo, C. M. \& Nogeira-Machado, J. A. (1981) J. Immunol. Methods 40, 115-116. 
8. English, D. \& Andersen, B. R. (1974) J. Immunol. Methods 5, 249-252.

9. Zigmond, S. H. \& Hirsch, J. G. (1973) J. Exp. Med. 137, 387-410.

10. Böyum, A. (1964) Nature 204, 793-794.

11. Skoog, W. A. \& Beck, W. S. (1956) Blood 11, 436-454.
12. Böyum, A. (1976) Scand. J. Immunol. 5 (Suppl. 5), 9-15.

13. Dewar, C. (1978) J. Immunol. Methods 20, 301-310.

14. Fallon, H. J., Frei, E., Davidson, J. D., Trier, J. S. \& Burk, D. (1962) J. Lab. Clin. Med. 59, 779-791.

15. Segal, A. W., Fortunato, A. \& Herd, T. (1980) J. Immunol. Methods 32, 209-214.

Henning Kelbæk, MD,

Medical Department C,

Herlev Úniversity Hospital,

DK $=2730$ Herlev 